\title{
Assessment of stigma and prejudice in the organization of care networks for drug users
}

\author{
Avaliação do estigma e preconceito na organização de redes de atenção aos usuários de drogas \\ Evaluación del estigma y prejuicio en la organización de redes de atención a usuarios de drogas
}

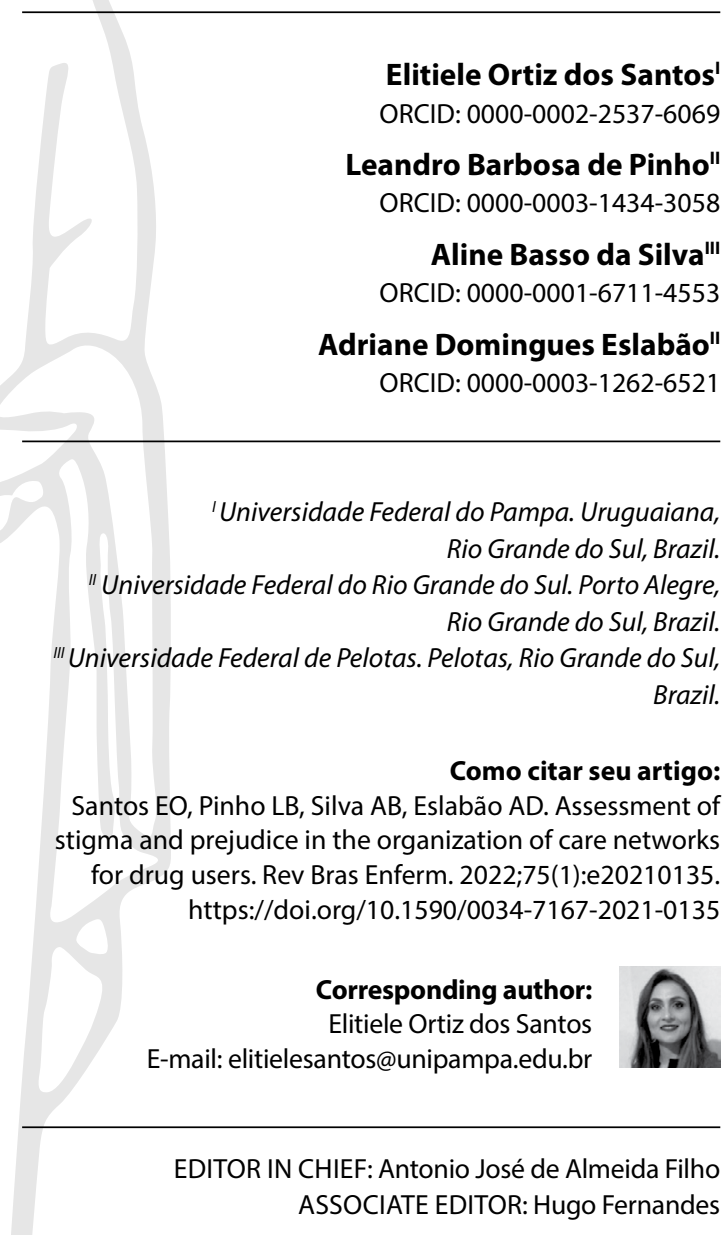

Submission: 03-24-2021 Approval: 05-03-2021

\begin{abstract}
Objective: To assess stigma and prejudice in the organization of the Psychosocial Care Network for drug users. Methods: this is a qualitative study, developed through Empowerment Assessment. The survey was conducted in a municipality in Rio Grande do Sul, with 42 network workers. For data collection, participant observation, semi-structured interviews and open forum were used. For data analysis, thematic analysis was used. Results: the network's mission involved a proposal for care without prejudice and judgments for drug users. It was identified that the composition of the network with training in multidisciplinary residency and psychiatry facilitates achieving the mission, and among the difficulties, the challenges to overcome prejudice were analyzed. Strategies for continuing education, seminars, and user empowerment in the community are suggested. Final considerations: stigma and prejudice need to be problematized in the networks for the organization of more inclusive and rehabilitating psychosocial care.

Descriptors: Drug Users; Social Stigma; Prejudice; Health Evaluation; Comprehensive Health Care.
\end{abstract}

\section{RESUMO}

Objetivo: avaliar o estigma e preconceito na organização de redes de atenção aos usuários de drogas. Métodos: estudo qualitativo, desenvolvido por meio da Avaliação de Empoderamento. A pesquisa foi realizada em um município do Rio Grande do Sul, com 42 trabalhadores da rede. Para coleta de dados, utilizou-se a observação participante, entrevista semiestruturada e fórum aberto. Para análise dos dados, utilizou-se a análise temática. Resultados: a missão da rede envolveu uma proposta de cuidado sem preconceitos e julgamentos ao usuário de drogas. Identificou-se que a composição da rede com a formação em residência multiprofissional e psiquiatria facilita o alcance da missão, e entre as dificuldades, analisaram-se os desafios para superar o preconceito. Sugerem-se estratégias de educação permanente, seminários e empoderamento do usuário na comunidade. Considerações finais: o estigma e o preconceito precisam ser problematizados nas redes para a organização do cuidado psicossocial mais inclusivo e reabilitador.

Descritores: Usuários de Drogas; Estigma Social; Preconceito; Avaliação em Saúde; Assistência Integral à Saúde.

\section{RESUMEN}

Objetivo: evaluar el estigma y los prejuicios en la organización de las redes de atención a los usuarios de drogas. Métodos: estudio cualitativo, desarrollado a través de la Evaluación de Empoderamiento. La investigación se llevó a cabo en una ciudad de Rio Grande do Sul, con 42 trabajadores de la red. Para la recolección de datos se utilizó observación participante, entrevistas semiestructuradas y foro abierto. Para el análisis de los datos se utilizó el análisis temático. Resultados: la misión de la red consistió en una propuesta de atención sin prejuicios y juicio a los usuarios de drogas. Se identificó que la composición de la red con formación en residencia multidisciplinar y psiquiatría facilita el logro de la misión, y entre las dificultades se analizaron los desafíos para superar los prejuicios. Se sugieren estrategias para la educación continua, seminarios y empoderamiento de los usuarios en la comunidad. Consideraciones finales: el estigma y los prejuicios deben problematizarse en redes para la organización de una atención psicosocial más inclusiva y rehabilitadora.

Descriptores: Consumidores de Drogas; Estigma Social; Prejuicio; Evaluación en Salud; Atención Integral de Salud. 


\section{INTRODUCTION}

Drug abuse is a complex flagship with challenges for global mental health. In Brazil, the policy of confronting drugs in its propositions gives rise to the clash between the Brazilian National Anti-Drug Policy, in the scope of public security, which follows the logic of prohibition, and the Policy of Comprehensive Care to Drug Users, guided by the logic of reducing damage. Both the Ministry of Health and the Ministry of Justice focus on the theme, resulting in a set of contradictions that mark the ambiguities of this problem in contemporary times ${ }^{(1)}$.

Based on the Policy of Comprehensive Care for Users of Alcohol and Other Drugs, presented in 2003, the intention was to reverse the directionality of actions centered on repressive approaches, for a care organization based on the Psychosocial Care Network (RAPS - Rede de Atenção Psicossocial), which characterized by the integration of various services and devices that must establish communication and co-responsibility for care from primary to tertiary care ${ }^{(2)}$.

The main objectives of RAPS are humanization, a focus on the subject and not only on the disease, social inclusion and the deconstruction of stigmas and prejudices linked to people with psychiatric disorders and drug users. Despite its objectives focused on comprehensive care, RAPS has its implementation strongly challenged by anti-drug guidelines, still based on prohibition and the only negative image of subjects who use drugs, criminalizing its use and promoting a stigmatizing and prejudiced culture in society ${ }^{(3)}$.

As central concepts, prejudice is approached as a inadequate judgment to define something or someone, building an idea without previous knowledge. Prejudice is characterized by the affirmation of own identity as superior/dominant, and likewise, by the denial of the other who is different ${ }^{(4)}$. Stigma, on the other hand, is a derogatory attribute that is attributed to an individual, which is part of a characteristic and becomes something totalizing ${ }^{(5)}$. The stigma extrapolates an attitude of prejudgment, and shows something like a infamous signal, unworthy and dishonorable, considered a stain on someone's reputation, undignified and dishonorable sign, a stain on someone's reputation ${ }^{(6)}$.

Stigma and prejudice towards drug users are related to a number of factors, such as the perception that drug use leads to people committing irrational acts, racist historical associations between certain drugs and certain populations, religious objections, and perceived interference in the neoliberal values that blame individuals and exempt the state from responsibility, with the exception of actions aimed at people who abuse psychoactive substances ${ }^{(7-9)}$.

Stigma and prejudice highlight a one-way view of drug use that is disseminated by the media vehicles of communication. There is an idea that all individuals who use the drug are chemical dependents, involved in drug trafficking and criminality. This social imaginary contributes to the social marginalization of users, obscuring the analysis of these people's lives and the social dimension of their determinants ${ }^{(10)}$. In the logic of social relationships, stigma and prejudice have been analyzed as part of the organizational dynamics that reflect the experiences of drug users in poor access to health services, as, because they feel ashamed and ignored, they find it difficult to seek help and/or complete care plans ${ }^{(11-12)}$.

Among the strategies that users use to avoid stigma is the delay in seeking treatment, not disclosing drug use and seeking care in other community resources not linked to health services ${ }^{(13)}$. In this sense, studies on this theme are necessary to analyze and understand how stigma and prejudice reflect in the context of networking, in order to promote that these people receive shelter in the health services of RAPS and feel encouraged to seek treatments and healthcare.

It is identified that qualitative evaluative research can favor, in contact with these complex issues, not only subjects' perspectives, feelings and values, but also the institutional structural processes such as the construction of healthcare networks. Thus, considering that RAPS organization must address issues related to the stigma and prejudice experienced by drug users and provide direct, comprehensive answers supported by different network arrangements, this study presents the following research question: how is stigma and is prejudice evaluated in the organization of RAPS for drug users?

\section{OBJECTIVE}

To assess stigma and prejudice in the organization of the Psychosocial Care Network for drug users.

\section{METHODS}

\section{Ethical aspects}

This study was approved by the Institutional Review Board of Universidade Federal do Rio Grande do Sul in 2017. Ethical aspects were ensured in accordance with Resolution 466/12 of the Brazilian National Health Council (Conselho Nacional de Saúde). To guarantee participants' anonymity, the statements were identified with the letter $W$ for worker, accompanied by the name of RAPS component that works, followed by Arabic numerals, according to the ascending order of interviews.

\section{Theoretical-methodological framework}

\section{Type of study}

This is an evaluative study, of a qualitative nature, using the methodological assumptions of Empowerment Assessment, a participatory assessment built collectively between researcher and research participants with the aim of qualifying social practices and technologies. This assessment is carried out through three steps: 1) Mission construction - aims to build the purpose of networking and unify efforts among participants to achieve the objectives of work; 2) Knowledge of current situation - seeks to identify the main facilities and difficulties of the network to achieve the mission; 3) Planning for the future - involves the elaboration and prioritization of strategies to achieve the mission ${ }^{(14)}$. 


\section{Methodological procedures}

\section{Study setting}

The research field was the RAPS of a small municipality in Rio Grande do Sul, Brazil, which was intentionally selected for being a reference in terms of network care from the perspective of psychosocial care, being a pioneer in the implementation of CAPS in the state. The municipality had an estimated population of 44,580 inhabitants in 2017, with approximately $50 \%$ residing in the rural area $^{(10)}$. It is a municipality of German colonization with one of the highest concentrations of Pomeranian descendants in the world ${ }^{(15)}$.

\section{Data source}

In this study, RAPS managers and workers participated. The inclusion criteria for the participants were: being a coordinator for at least one month in the network service and, for workers, having at least six months of employment.

For the production of data, the triangulation of qualitative methods was used: semi-structured interview, participant observation and open forum ${ }^{(14)}$. Semi-structured interviews were applied to 42 workers from the following network components: 18 workers from the Primary Healthcare component (harm reduction, central health unit, Family Health Strategy (FHS), and Family Health Support Center); 9 from strategic psychosocial care (Alcohol and Drugs Psychosocial Care Center-CAPS (Centro de Atenção Psicossocial) AD, CAPSI, Children CAPS); 1 from emergency care (Mobile Emergency Care Service); 1 from hospital care (specialized ward in chemical dependency; 1 from psychosocial rehabilitation strategies (service of job and income generation); 3 RAPS managers (coordination of mental health, primary care and teaching, research and extension); 5 of social assistance (Department of Social Assistance, Social Assistance Reference Center, Specialized Social Assistance Reference Center, Children's Home, Beat Early Childhood); 4 from the intersectoral network: (custodial council, school, judiciary and Public Ministry). The interviews were carried out individually during the work shift in a reserved room of the service in order to guarantee privacy, later they were recorded and transcribed in full. The interviews lasted approximately 35 minutes.

Another technique used was participant observation, which is characterized as an instrument that enables approximation with participants and the research context ${ }^{(16)}$. Participant observation took place for a period of nine months in the morning and afternoon shifts at RAPS services. The records of this observation were carried out in a field diary.

Finally, Open Forum was a technique used to negotiate the research data, prioritize RAPS' mission and planning strategies for the future, and included the participation of professionals who are part of the management collegiate: 3 RAPS managers (Mental Health Coordinator, Primary Care Coordinator, and Multidisciplinary Residency Coordinator) and representative of the network components (CAPS AD III, CAPS I, Child CAPS and SAMU).

\section{Data collection and organization}

Data collection was carried out between March and December 2017. The Consolidated Criteria for Reporting Qualitative Research (COREQ) was used as a criterion for data organization.

\section{Work steps}

As this was a qualitative evaluative research of a constructivist character, at first there was the construction of a bond with the community to gain the right of entry, which is about raising participants' awareness for involvement with the research proposal. In this sense, participant observations began, mainly in CAPS AD activities, in its internal dynamics and in the spaces and connections with RAPS and the intersectoral network. The observations' focus sought to meet the actors in order to understand how the network was organized and operated, identifying what the local RAPS' mission would be, the aspects that facilitated and hindered the work, and the improvements that could be invested for qualification of this network. All these questions were also addressed in semi-structured interviews, in order to hear the perception and experience of research participants.

Finally, the open forum was held, the differential of this research in the light of Empowerment Assessment. In the open forum, the main researcher facilitated a data negotiation process through the presentation of the summary of empirical material, encouraging participants to reflect and participate in decisions on the points that would need to be prioritized and invested in the local network, such as the local network's mission, current situation, and strategies to be invested for the network's future, taking into account current priorities, local possibilities, and what could actually be invested. In these spaces, stigma and prejudice in RAPS emerged as a unit of analysis for the construction of the local network.

\section{Data analysis}

Thematic analysis was used, carried out through three steps: data ordering, data classification and final analysis. In the first, text skimming and exhaustive reading of the collected material is made. In the second, excerpts and fragments were separated, which were distributed into topics, identified as information units, and then approximated by similarity, originating the units of meaning. Finally, the final analysis with a view to interpreting the results obtained ${ }^{(16)}$. In this article, stigma and prejudice is addressed in the light of Empowerment Assessment in its three stages: Psychosocial Care Network's mission; Knowledge of current situation; Planning for the future.

\section{RESULTS}

Among the 42 workers participating in the study, 18 are nurses, eight psychologists, six social assistants, three psychiatrists, two harm reducers, an educator, a prosecutor, a judge, a physical educator and an occupational therapist. Of these workers, 36 are female. Regarding time working in the network, 11 workers have been working with RAPS for over ten years; 11 workers have an employment relationship between 2 and 9 years; 10 workers for a period equal to or less than one year. The results of this study and its respective stages will be presented below.:

\section{Psychosocial Care Network' mission}

For participants, RAPS' mission in the city involves a proposal for care without prejudice and judgment regarding drug users. 
Unconditionally welcome the subject in its entirety, without stigma, without prejudice, without value judgments [...] this stigma, this user label is related to criminality, violence, robbery, trickery, shamelessness, this is still spends a lot in the collective unconscious of society and this ends up reproducing many times, but often even by the professionals themselves [...]. (W1 Strategic Psychosocial Care)

It's taking care of these people without judging, you know, it's surrendering without prejudice, without judgment, without thinking that people are pretending, or that they're doing it [...] I think we're here to perform our services, assist these people, we are a public agency. (W37 Social Assistance)

Demystifying the issue of alcohol and drug use, [...] there is a lot of prejudice, and also prejudice from the users themselves. (W5 Strategic Psychosocial Care)

\section{Knowledge of current situation}

At this stage, the aspects that facilitate and hinder the achievement of RAPS' mission in the construction of care without prejudice and judgment in the attention to drug users were evaluated.

According to participants, the facilitating aspects are the configuration of RAPS in constituting itself as a training field in the modality of psychiatric residency and multidisciplinary residency, as it promotes greater contact between professionals with the debate on current public policies based on harm reduction and in extended care to drug users.

[...] this contact that we now have with the other services that make up the network and through continuing education, in which followed in our own meetings, there is, for example, a resident, or from the multi, or from the psychiatric residency, brings some related issue to the care of users on alcohol and other drugs, and we see, for example, the presence of professionals, of other services [...] today you can say that this is what has made it easier, because today you have assimilated the idea of the policy more of harm reduction, of not stigmatizing users, a broader look. (W1 Strategic Psychosocial Care)

The residency helped a lot, this contact, in the teams that the residency is in, which are not all, I think it helped a lot. It's like I tell you, when you have someone to keep an eye on you, you end up policing you. (W9 Strategic Psychosocial Care)

Another important element of RAPS' mission is training, to be a space for permanent training and education for workers, for all professionals, I think it is an important experience that we have here. (Open Forum)

Among the aspects that make it difficult to achieve RAPS' mission, professionals highlight the practices of prejudice carried out in the network, which reinforces the stigma related to drug users present in the social imagination.

Sometimes, in this first service, there is already a judgment, there is already a label. Unfortunately, there's a lot of it, "ah, but the guy I know, the guy just wants such a thing", it's this label, and if I say that to you, you'll have the same perception as me, and then a whole team sometimes is contaminated by something that is just a perception and that is not true, and then I won't be able to help that person. So, unfortunately, it happens. Small town. (W26 Primary Health Care)

[...] I think there's a lot of prejudice, it's a very glaring thing like that, sometimes we have to police ourselves too, because we have our prejudices, I think sometimes, the person is so unstructured that we sometimes can't, we let our emotions flourish [...]. (W4 Strategic Psychosocial Care)

In the case of the network under study, professionals demonstrate that the stereotype of drug users, as people without commitment and incapable, made it difficult for the network to "see" users' roles played in society.

[...] there was already a case that because the mother drank she was bad for her daughter, and she was always an extremely careful mother, at that time she was confused, but from the moment she resumed treatment it flowed, today she is a super mother, she lives in a context very complicated, but she treated that daughter well and [service X] couldn't see it that way. (W4 Strategic Psychosocial Care)

[...] prejudice in the sense of not understanding that it is a disease, [...] and she is a very affectionate, very affectionate mother, the children miss her a lot, it is very difficult [...] it is the real mother with her ducklings [...]. (W35 Social Assistance)

According to participants, the prejudice of professionals often makes it difficult to link service users and proposed therapies as well as to network care:

W3 reports the prejudice of professionals when assisting user $C$. She says that during hospitalization, the colleagues who made the reception were judging: I had to say, "imagine how difficult it must be for her, put herself in her place". (Field Diary)

Psychoactive substance users who are very labeled by society, very stigmatized, and in this logic ends up being labeled and stigmatized by the services themselves, for example, until a while ago [...] the person mentioned that they used alcohol or that they used some substance, they were not even attended to, they were already referred to CAPS and today we know that CAPS is to attend to the crisis and when the person comes out of the crisis, they have to be assisted in their territory, but for that we have to evolve a lot. (W1 Strategic Psychosocial Care)

It would need to improve a lot, remember that I spoke earlier about prejudice, I think it is glaring there. [...] they have already been stopped, by an ugly face, poor service, many said they would never set foot there again. [...]. It would need to improve the articulation, total. (W3 Strategic Psychosocial Care)

Prejudice towards drug users also interferes in the conception of services that serve this public, so that CAPS AD is often considered by the community as a service for "nuts people".

Services exist, their doors are open, waiting for patients. The biggest difficulty is sometimes the user to go. We can already access, 
guide, but when you say that he should go to an appointment at the CAPS, they are a little frustrating, they think, "Oh, but I'm not mentally ill'. (W18 Primary Health Care)

A difficulty, therefore, because users who do not attend any service. [...] it's not prejudice, but it's a shame to get to the services. Even by discrimination, from society in general [...]. (W28 Primary Health Care)

\section{Planning for the future}

Professionals highlight the need to strengthen permanent education strategies with dialogue, training, seminars, training involving professionals from specialized services and primary care.

Lack of preparation, lack of qualification. If there was a professional who was more present in the team, demystifying this issue, it would suddenly make it easier. (W16 Primary Health Care)

[...] train more basic care again for evaluation, in mental health, not only in alcohol and drugs, with systematic training, case discussion, qualify the discussion of cases in mental health, [...] we have already started this year with the inclusion of harm reduction at health posts, in the field. (W2 Strategic Psychosocial Care)

[...] let's suppose there was a seminar, to talk better about things, to bring people, to give us a little knock, because we know a little bit, [...] I think there could be more events to bring together all staff [...]. (W36 Intersectoral Network)

Participants also suggest user empowerment in community spaces:

[...] how much we have to work on it and show them that they are capable of being in any space, that they can occupy these spaces, that it is not written, I am an alcohol and drug user, [...] so, I see in my area the challenge is to occupy the territory more and more, showing them that they can occupy it in a healthy way, with a different perspective [...]. (W5 Strategic Psychosocial Care)

What I always thought, that if I could, when these patients were stable and able to have an occupation, would be work, which I think you can achieve a lot there. (W9 Strategic Psychosocial Care)

I think the possibility of these workshops in neighborhoods, of being able to have more things, more production, I think thinking about the evolution of networking, [...] having something related to placement in the service. (W7 Strategic Psychosocial Care)

\section{DISCUSSION}

In the focus of Empowerment Assessment framework, the organization of care in attention to drug users is composed of an active participation of professionals in the construction of networks. To this end, their ideas and reflections on RAPS' mission, the current situation and perspectives for the future, bring a problematic analysis in relation to prejudice and stigma as aspects that need to be considered for the promotion of networked care for drug users.

In the first category, RAPS' mission is evaluated, in which W1, W37 and W5 highlight a care proposal in a network aimed at welcoming without prejudice, value judgment and judgment.
Participants emphasize that it is necessary to demystify the social stigmas of drug users. These ideas are exemplified by W1, which addresses the association of drug use with crime, violence, trickery, and this reflects in the practices of health professionals and in the work process, generating situations of prejudice.

For users, there is also the constitution of a self-stigma that occurs due to the internalization of beliefs associated with drug use, starting to believe that they have less value due to their "condition"(17). These aspects are experienced by users in the network under study and have affected access and treatment in health services. Thus, the fight against stigma and prejudice are considered priorities of the network, constituting the collective mission listed.

The mission constructed by participants demonstrates the need to change the culture of marginalization of drug users, based on the problematization of the processes of social exclusion, negligence practices, absence of specific policies and inequality in the conditions of citizenship. The inclusion of this agenda in networking can contribute to paradigm shifts and the construction of a new form of care that brings the perspective of living with differences and guaranteeing rights in care practices ${ }^{(18)}$. Combating stigma and prejudice is a political guideline for the functioning of RAPS according to Decree 3.088 of 2011 that institutes RAPS within the scope of the Brazilian Unified Health System (Sistema Único de Saúde - SUS). However, managers face the challenge of operationalizing them in the territory considering the local potentials and challenges, as well as the municipality's cultural issues and needs.

In the knowledge of current situation of RAPS, one of the aspects identified as a facilitator for achieving the mission is the network configuration as a training field in the modality of psychiatric residency and multidisciplinary residency. This composition promotes greater contact between professionals and the debate on current public policies based on harm reduction and expanded care. This is pointed out mainly in the testimonies of W1 and W4, which highlight the exchange of experiences with other professionals as a possibility of continuing education and awareness of the teams that can generate knowledge and reflection on the theme of stigma and prejudice within the clinic, policy, theory and practice of care.

These data are related to a study that analyzes Multidisciplinary Residencies as tools for the construction of other ways of looking at healthcare, reflecting the frequent need to revisit the ethical behavior according to the principles of SUS and the expanded clinic. The worker-resident meeting manifests processes of change that can be powerful for mental health care and for the advancement of Psychiatric Reform ${ }^{(19)}$.

Although there are challenges in the articulation between residency and services, such as the stressful conditions generated in this process ${ }^{(20)}$, residency presents itself as a potential for both the training of residents and the permanent training of health workers. In addition, it is a strategy that to building new ways to involve and articulate professionals for humanized practices, and, in this way, to overcome the fragmentation of care. This reality produces innovative perspectives and consonant to the premises of psychosocial care that provide subsidies for qualification of RAPS and the reach of their proposals. 
Among the aspects that make it difficult to achieve RAS' mission- in its proposal of care without prejudice and judgments regarding drug users, W6, W4 and W35 highlight the challenges of overcoming the prejudice practices present in RAPS, i.e., of not to reproduce prejudiced practices in environments destined to care.

In the work of the network professional, there is often an evaluation accompanied by a judgment and not based on users' needs. A factor that influences this assessment is the fact that the municipality is small, where professionals and users know each other from other spaces and have proximity between their networks of relationships, with the even greater challenge of restituting the roles occupied in the network and conducting an assessment ethics based on needs. This is exemplified in the speech of W4, in which it is clear that prejudice is linked to a negative image, the fact, for example, of seeing only the use of alcohol in the relationship between mother and daughter, disregarding that in this relationship there was also care and attention to the daughter.

Studies confirm that the professional approach regulated by prejudice negatively interferes with citizenship opportunities and the search for access to health services ${ }^{(21-23)}$. Teams often view drug users as violent, manipulative, noncommittal, and resistant to treatment. For some professionals, substance use provokes aggressive and delinquent behavior, such as robberies, assaults and homicides. This perception, associated with the weaknesses of infrastructure, training and qualification of the teams, generates feelings of fear and insecurity in professionals, perpetuating repressive, authoritarian and abstinence-oriented asylum practices ${ }^{(21-23)}$.

In the case of this research, this is also identified, in which prejudiced practices on the part of professionals can interfere in the way a given case will be conducted in the network and in the actions offered, which can be a barrier for users to link to teams and adhere to therapy. An assessment based on prejudice can reinforce isolated and punctual practices without seeking, in the network, articulation strategies to contribute to solving problems and acting on needs. For example, we can mention the stories brought by $\mathrm{W} 3$ and $\mathrm{W} 1$ that mention the poor service provided by professionals from some services in the network.

It is understood that a relationship between professional and user based on stigma and prejudice can generate negative consequences due to the fact that many people do not seek help in services in order not to be "labeled". This reduced access to the service can increase drug abuse problems, generating other psychic comorbidities and making the complexity of life and people invisible to the health and social system. Furthermore, it can result in poorer and less organized services and in the devaluation of professionals involved ${ }^{(17)}$.

From the perspective of networking, attention is drawn to the articulation between RAPS services and the development of an integrated work proposal. It is observed as a result of research that there is still a demand for drug care focused exclusively on CAPS. This centrality can reinforce stigmatization and put at risk the RAPS' proposal, since treatment and social reintegration depend on this continuity of care and to maintain the bond in RAPS, it is necessary that all teams are welcoming.

In this sense, prejudice must be worked in the network, without attributing the problem to a specific service or professional. It is about recognizing prejudice as a barrier to network care, seeking joint strategies without a rupture between services. One of these strategies is the clarification between professionals and users about the work of each service, its objectives and missions, also seeking to demystify stigmas about madness and mental health and the image that CAPS is the only service to assist drug users.

In the speech of W4, it is also possible to see the importance of the professional's self-reflection on the practices he develops, demystifying the idea that prejudice is something done "by the other". This analysis repositions prejudice to the scope of mental health care and can contribute to the construction of practices based on ethics and the qualification of network care, in addition to enabling the vision of the roles of users in society, including their socio-cultural issues.

In the field of drug use, there is a conception based on common sense, in which the complexity of people's lives is not observed. In this regard, the teams face the challenge of giving new meaning to their practices, avoiding the perpetuation of simplistic conceptions that lead to prejudiced and excluding approaches, such as referring all drug users who access the network to specialized services. This conduct reinforces CAPS image as the only place of care for drug use and distances users from comprehensive care and inserted in society.

Studies in South American countries also point out the referral of professionals to specialized services due to prejudice in drug user care ${ }^{(22,24)}$. In the case of FHS, these teams commonly report little skill and competence for the approaches. The professionals' discourse is still linked to dangerousness, which has led the teams to deny the reception and have as main answer the referral to the specialized service ${ }^{(25)}$.

W28 also points out prejudice as a barrier to access and treatment in specialized services, being a characteristic of social vision and discrimination. Users are often afraid to attend CAPS AD or any health service, fearing they will be labeled as people with mental problems in their communities. This is observed in the literature, which points out that stigma and prejudice can lead people to seek treatment in protected environments, such as clinics and places far from interactions with family and friends ${ }^{(26)}$.

As perspective strategies for the future of the network, W16, W2, W36 suggest investment in permanent education, involving dialogue between CAPS AD and FHS with a view to qualifying primary care for the care of drug users. The frequent presence of CAPS AD professionals in FHS is a strategy that can contribute to the discussion of cases and shared care, being considered a necessary tie to reach the RAPS' proposals.

Another suggestion for RAPS is professional qualification with courses, seminars, reflections on practices and motivation for teams. Workers emphasize that professional qualification is often seen as an individual responsibility. However, it is necessary to implement training as part of the network's actions to broaden collective understanding of policies and connect workers to the same efforts.

Health professionals' training needs to be permanent based on experiences and reflections as a possibility for new knowhow, linking management, care and social participation for the construction of a strengthened network ${ }^{(27)}$. These ideas meet the research participants who are interested in social change in the 
care of drug users. From their testimonies W5, W9 and W7, they reflect on the importance of empowering users through social reintegration in the territory and in the job market, workshops in the neighborhoods and the search for other possibilities in the community, strengthening this relationship. This is also evidenced in other studies ${ }^{(28-29)}$ that point out as great challenges users' access to a productive life that can legitimize socially, providing greater self-esteem and quality of life.

Finally, although it is a slow and gradual process, it is essential to deconstruct the social imaginary that frames drug users in some abnormal status within society's standards. This permeates intersectoral work, such as the economy, the labor market, education and social assistance, i.e., organizations beyond RAPS' work, linked only to health, but which are connected with the development of integration strategies between service and society.

\section{Study limitations}

The study is characterized by the assessment of RAPS professionals and managers. We suggest other evaluative studies with users and family members of the network, contemplating their participation in the construction of local networks, in order to broaden the understanding of the problems and their resolutions collectively and identify ways to qualify the network in the light of the psychosocial paradigm.

\section{Contributions to health and public policies}

Contributions are identified as the proposal for a participatory evaluative process, which reveals qualitative research, in addition to collecting data and information, but also as a proposal for meeting, dialogue, professional training, discussion about potential, difficulties and contributions to the advancement of comprehensive care practices for drug users at the local level.

Another relevant issue is to bring up the debate on prejudice and stigma that is often overlooked in the demands of services, routines and techniques in the field of mental health. Discussing and demystifying stigmas and prejudices contributes to the advancement of public policies on mental health for drug users, expanding their access to comprehensive, humanized and ethical care.

\section{FINAL CONSIDERATIONS}

The local RAPS mission demonstrates the need to transform a culture that marginalizes drug users, through an image and stereotype that produces social stigmas both in society, health professionals and users. To build a welcoming network, it is essential to face this stigmatization process.

Regarding analysis of current situation, the work of professionals in training spaces with psychiatric residency and multidisciplinary residency, where students and front-line professionals can discuss, learn and demystify practices based on prejudices and stigmas. The complicating factors of this process, on the other hand, are related to the production of prejudiced practices in environments that should be of care, producing barriers for users' adherence to therapy, in addition to users' fear of labeling services both by health professionals and by society, which makes it difficult access to and continuity of care in RAPS.

It addresses as a perspective for the future the need for greater investments in education and permanent professional training, the integration between primary care and CAPS AD as well as strategies aimed at reinserting users into society for income generation and visualization as citizens. These results contribute to the construction of networked psychosocial care in tackling drug abuse, integrating services and society with a broad fight against moralism and stigmatization, promoting participatory and inclusive care spaces.

\section{SUPPLEMENTARY MATERIAL}

The article is the result of a PhD. thesis at the Federal University of Rio Grande do Sul (UFRGS), therefore, published in the repository lume.ufrgs.br. The thesis can be found at the following link: https://lume.ufrgs.br/bitstream/handle/10183/201252/001105181. pdf? sequence=1\&isAllowed $=y$

\section{ACKNOWLEDGMENT}

To the Coordination for the Improvement of Higher Education Personnel (CAPES - Coordenação de Aperfeiçoamento de Pessoal de Nível Superior) for granting a Graduate Scholarship to the first author.

\section{REFERENCES}

1. Vargas AFM, Campos MM. A trajetória das políticas de saúde mental e de álcool e outras drogas no século XX. Ciênc Saúde Colet. 2019;24(3):1041-50. https://doi.org/10.1590/1413-81232018243.34492016

2. Costa PHA, Ronzani TM, Colugnati FAB. "No papel é bonito, mas na prática..." : análise sobre a rede de atenção aos usuários de drogas nas políticas e instrumentos normativos da área. Saúde Soc. 2017;26(3):738-50. https://doi.org/10.1590/s0104-12902017170188

3. Rybka LN, Nascimento JL, Guzzo RSL. Os mortos e feridos na "guerra às drogas": uma crítica ao paradigma proibicionista. Estud Psicol. 2018;35(1):99-109. https://doi.org/10.1590/198202752018000100010

4. Bandeira L, Batista AS. Preconceito e discriminação como expressões de violência. Estud Femin. 2002;(10):119-41. https://doi.org/10.1590/ S0104-026X2002000100007

5. Goffman E. Estigma: notas sobre a manipulação da identidade deteriorada. Rio de Janeiro: LTC; 2015.

6. Schilling F, Miyashiro SG. Como incluir? o debate sobre o preconceito e o estigma na atualidade. Educ Pesqui. 2008;34(2):243-54. https://doi. org/10.1590/S1517-97022008000200003 
7. Fraser S, Moore D, Farrugia A, Edwards M, Madden A. Exclusion and hospitality: the subtle dynamics of stigma in healthcare access for people emerging from alcohol and other drug treatment. Sociol Health Illness. 2020;42(8):1-20. https://doi.org/10.1111/1467-9566.13180

8. Tyler I, Slater T. Rethinking the sociology of stigma. Sociologic Rev. 2018;66(4):721-43. https://doi.org/10.1177/0038026118777425

9. Roos CM, Bard ND, Silva AB, Olschowsky A, Pinho LB. Portraits on the crack user built by the media. Rev Bras Enferm. 2018;71(Suppl5):2368-73. https://doi.org/10.1590/0034-7167-2017-0826

10. Bard ND, Antunes B, Roos CM, Olschowsky A, Pinho LB. Stigma and prejudice: the experience of crack users. Rev Latino-Am Enfermagem. 2016;24:1-7. https://doi.org/10.1590/1518-8345.0852.2680

11. Fraser S, Pienaar K, Dilkes-Frayne E, Moore D. Addiction stigma and the biopolitics of liberal modernity: a qualitative analysis. Int J Drug Pol. 2017;44:192-201. https://doi.org/10.1016/j.drugpo.2017.02.005

12. Rossi CCS, Tucci AM. Acesso ao tratamento para dependentes de crack em situação de rua. Psicol Soc. 2020;32:1-18. https://doi.org/ 10.1590/1807-0310/2020v32170161

13. Biancarelli D, Biello K, Childs E, Drainoni M, SalhaneyP, et al. Strategies used by people who inject drugs to avoid stigma in healthcare settings. Drug Alcohol Depend. 2019;198:80-6. https://doi.org/10.1016/j.drugalcdep.2019.01.037

14. Fetterman DM, Kaftarian SJ, Wandersman A. Empowerment evaluation. New York: Sage; 2015.

15. Instituto Brasileiro de Geografia e Estatística (IBGE). Brasil, Rio Grande do Sul, São Lourenço do Sul[Internet]. 2020 [cited 2021 Jan 22]. Available from: https://cidades.ibge.gov.br/brasil/rs/sao-lourenco-do-sul/panorama

16. Minayo MCS. O desafio do conhecimento: pesquisa qualitativa em saúde. 13. ed. São Paulo: Hucitec; 2013.

17. Sousa JF. O estigma da saúde mental. Psicologia.pt [Internet]. 2017 [cited 2021 Jan 24]:1-7. Available from: https://www.psicologia.pt/ artigos/textos/A1120.pdf

18. Pereira MO, Vargas D, Oliveira MAF. Reflection on the policy of the Brazilian Ministry of Health for the care of alcohol and other drugs users under the view of the sociology of absences and emergencies. Rev Eletrôn Saúde Mental Álcool Drog. 2012;8(1):9-16. https://doi. org/10.11606/issn.1806-6976.v8i1p9-16

19. Wetzel C, Kohlrausch ER, Pavani FB, Batistella FS, Pinho LB. Analysis of interprofessional in-service education in a Psychosocial Care Center. Interface. 2018;22(suppl.2):1729-38. https://doi.org/10.1590/1807-57622017.0664

20. Oliveira EB, Zanesco C, Bordin D, Cabral LPA, Brasil D, Fadel CB. Stress in multiprofessional health residence: nature and magnitude. Braz J of Develop. 2019;5(11):157-66. https://doi.org/10.1590/1981-52712015v43n4rb20190031

21. Paula ML, Jorge MSB, Vasconcelos MGF, Albuquerque RA. Assistência ao usuário de drogas na atenção primária à saúde. Psicol Estud. 2014;19(2):223-33. https://doi.org/10.1590/1413-7372222025006

22. Hildebrandt LM, Marcolan JF. Concepções da equipe de enfermagem sobre assistência psiquiátrica em hospital geral. Rev Rene. 2016;17(3):378-85. https://doi.org/10.15253/2175-6783.2016000300011

23. Otálvaro AFT, Vallejo GAC, Escobar SMR, Gallón VV, Giraldo ICO. Estigma social de profesionales de la salud hacia personas que usan drogas. Psicol Pesqui. 2019;13(1):22-32. https://doi.org/10.24879/2018001200300478

24. Barreto MS, Buchele F, Queiros LA. A atenção prestada aos usuários de substâncias psicoativas em Unidades de Pronto Atendimento por enfermeiros e médicos. Saude Transf Soc [Internet]. 2015 [cited 2021 Jan 10];6(3):62-76. Available from: http://incubadora.periodicos.ufsc. br/index.php/saudeetransformacao/article/view/3495/4487

25. Dimenstein M, Leite J, Macedo JP, Dantas C. Condições de vida e saúde mental em contextos rurais. Serv Soc Saude. 2017;16(1):151-8. https://doi.org/10.20396/sss.v16i1.8651478

26. Woodheada EL, Timko C, Xiaotong H, Cucciared MA. Stigma, treatment, and health among stimulant users: life stage as a moderator. J Appl Dev Psychol. 2019;60:96-104. https://doi.org/10.1016/j.appdev.2018.11.005

27. Emerich BF, Onocko-Campos R. Formação para o trabalho em Saúde Mental: reflexões a partir das concepções de Sujeito, Coletivo e Instituição. Interface. 2019;23:1-15. https://doi.org/10.1590/interface.170521

28. Mazaro LM, Matsukura TS, Lussi IAO. Solidarity economy as a social inclusion strategy through work in the field of mental health: national overview. Cad Bras Ter Ocup. 2020;28(1):127-46. https://doi.org/10.4322/2526-8910.ctoao1880

29. Pinho LB, Wetzel C, Schneider JF, Olschowsky A, Camatta MW, Kohlrausch ER, et al. Evaluation of intersectoral resources in the composition of care networks for crack users. Esc Anna Nery. 2017;21(4):1-8. https://doi.org/10.1590/2177-9465-ean-2017-0149 